\title{
The Pros and Cons of New Media and Media Freedom
}

\section{Vineet Kaul*}

Department of Communication and Media, DA-IICT University, Near Indroda, Gandhinagar, Gujarat, India

\begin{abstract}
In Asian Countries media freedom is a controversial issue, on one side right to information and freedom of expression is provided on other side media regulations and Press laws are ready to curb the media freedom. New media often get involved in struggles for new freedoms. This article is to discuss issues of new media in the governance of freedom of press. The Internet is an indispensable source of information today. At the same time, the freedom of new media - like other media - is dynamically related to the overall societal context as regards press freedom dispensations. Old and new media realms do have different issues, and there are particular matters for developing countries. But there is also much in common between old and new media, and between developing and developed countries, and all have interdependent interests in a free environment for journalism. With the creation of various types of new media, the Internet has become the broadest gateway and platform of spatial knowledge to interaction, and even turns to be the formation of a far and wide public field. The emergence of new media which breaks the original concept and rules of traditional media communication makes expression of freedom of the press more influential. There are brand new challenges to media freedom. The Internet, social media and blog posts -these are among the tools being used so creatively, especially by the vanguard of young people, to help spur change in their societies.
\end{abstract}

Keywords: Freedom of press; New media; Traditional media, Media communication, Freedom of expression

Press organisations are vibrant and restive institutions which provide platforms for power negotiations in the public space. They set the stage for public discourse on popular issues and enjoy wide readership. The principal features of press organisations include critical independence, democratic constructiveness and commercial viability [1-3]. The state's fear of the power of press organisations and their immense contributions to the defence of fundamental human rights often serves as justification for censorship. Although freedom of the press is guaranteed in the First Amendment, to what extent that right is protected has been battled in court and debated in public opinion for more than 200 years. Historically, "press freedom" is known as such because it was printers and newspapers that fought for this right which nowadays refers to media in general. It is a right that goes beyond an individual's freedom of expression, much as it is also built upon that right. In many places, it is privately-owned newspapers that continue this quest or help preserve victories against powerful forces who are sensitive to certain information becoming public. The question to be addressed in this paper therefore is the extent to which the battleground of press freedom today has a new frontier that incorporates cyberspace. This also entails taking stock of the main forces in the realm of new media (besides newspapers' presence there), and indeed whether old and new media are even on the same side in respect of this new arena. There are also questions of tools, tactics and issues in the contest for and against "press freedom" in this non-traditional environment. What, in short, are the new battles being fought, how do they affect "old" ones, and vice versa? And how does all this relate to "developing countries"?

In India media is always misused by political parties for the purpose of misrepresentation many politicians particularly in south India Where they have started private channel either on their name or on their relatives. Jaya TV, Surya TV etc. are good examples. Advertisements of India Shining, spiritualistic image making of political leaders are very common practice over Indian media. There are at least three major media traditions in modern India - that of a diverse, pluralistic and relatively independent press; of the manipulated-misused, statecontrolled radio and television; and that of many autonomous, small media outfits of various subaltern groups and their organizations. These traditions are so diverse, their histories, functions and roles in society and politics so divergent, and the rules of the game pertaining to them so radically different that any attempt to speak in a generalized way of the 'media' in India today and locating it in 'democracy' appears far-fetched.

The face of Indian media has been fast changing with the growth of the Internet, the phenomenal rise of satellite and cable networks, the continuing growth of regional press, despite various challenges and the blurring of lines between news and entertainment. But there is a sort of 'crises in the present media due to processes of commercialization, mercerization and commoditization. This has led some to present a pessimistic view of the media, to emphasize the ascendancy of 'infotainment' over 'serious' reportage and analysis of politics. It is also often remarked that the quality of 'serious' political journalism is steadily declining, with a dilution in its substantive political content to the detriment of the democratic process. An opposite view asserts not that there is too little serious politics in the media, but too much. This is seen as a kind of information overload that bores audiences and diminishes public interest. Still others have argued that media is an elitist bourgeois construct, reflecting essentially bourgeois interests and values and conditions of existence and can thus never serve the genuine interests of the people as a whole. Despite its democratic façade, it is said that the media remains exclusive, and people as a whole feel no real involvement in a process which appears to give them power but in reality does not.

*Corresponding author: Vineet Kaul, Department of Communication and Media, DA-IICT University, Near Indroda, Gandhinagar, Gujarat, India, Tel: 0919825934642; Fax: 26831400; E-mail: vineetkaul2404@gmail.com

Received March 31, 2012; Accepted April 13, 2012; Published April 15, 2012

Citation: Kaul V (2012) The Pros and Cons of New Media and Media Freedom. J Mass Commun Journalism 2:114. doi:10.4172/2165-7912.1000114

Copyright: (c) 2012 Kaul V. This is an open-access article distributed under the terms of the Creative Commons Attribution License, which permits unrestricted use, distribution, and reproduction in any medium, provided the original author and source are credited. 
In the last decade of the century, it appears that the new media communication system developed one hundred years ago is coming to an end, while a new system, whose characteristics and nature are not yet quite clear, is nevertheless certainly coming into being. When the automobile was invented, many thought it was just a horseless carriage. They did not realize that a new transforming feature of the culture of the entire twentieth century had arrived along with the reality of these four-wheeled motorized artifacts. The same question can be asked now: what is the new media technology culture that is coming with the computer and computerized information, and how are we to live with it? The year 2010 firmly established the role of social networks and the Internet as mobilisation and news transmission tools. In 2010 alone, 250 million Internet users joined Facebook and by the end of the year, the social network had 600 million members. In September that year, 175 million people were Twitter users - 100 million more than in the previous year.

A remarkable feature of the latter half of the twentieth century is the phenomenal growth rate of new communication technology. This rapidly-evolving technology ensures a quick and instantaneous information flow across the world while extending the communication pattern in different societies. New technologies in telecommunications, broadcasting and printing have also created greater opportunities for information flow among the world community. At the microcosmic level, the new technologies of satellite broadcasting, electronic printing, cable networks, telex, teletex, videotex systems, facsimile, digital telephony, telematics and video are enhancing access to multifarious communication sources and messages[4]'. There are ample manifestations that the next century will be dominated by new communication technology that could accentuate the technological and information gap between the industrialized world and much of the developing world, especially the poor societies at the periphery of the communication revolution. However, the new technologies are gradually creeping into many regions, and urbanized areas, particularly capitals of respective countries and increasingly exhibiting signs of the technological revolution.

Despite the revolutions of 1989, some eighty-two different kinds of censorship are still practiced worldwide. Censorship takes many forms, from murdering journalists to putting highly sophisticated forms of pressure on reporters and media managers. Altogether, systematic pressures induce a high degree of self-censorship which is harder to detect than outright blue-penciling of articles before publication or broadcasting. Censors operate more or less openly, depending on the degree of outright centralizing of government and of state control over mass communications. The revolutions of 1989 in Central Europe demonstrated the intimate connection between the systems of governance and the uses of mass communication for retaining or - as we saw that year - undermining highly centralized governments and societies.

The new is new. The technologies that have emerged in recent years, principally but not exclusively digital technologies, are new. They do new things. They give us new powers. They create new consequences for us as human beings. They bend minds. They transform institutions. They liberate. They oppress. It is not difficult to identify the utopian, nor indeed the dystopian, in all of this. It is not difficult either to see how often the desire for or fear of change overwhelms its analysis. It is easy to be seduced by the simplicity and the significance of novelty. It is easy to misread the signs. Novelty is, however, at this point, our problem. To ask the question 'what is new about new media?' is, of course, to ask a question about the relationship between continuity and change; a question that requires an investigation into the complexities of innovation as both a technological and a social process. But it is a question which also requires an interrogation of some fundamental presuppositions in social science as well as a confrontation with some of its enduring paradoxes.

These new technologies have great potential to democratize the countries where they are introduced and are permitted to function. Indeed, the Revolutions of 1989 in Eastern Europe, like that in the Philippines in 1987, were party motored by these new communications technologies. The peoples' revolutions were inspired, informed and guided by the use of television and the newer media. A similar phenomenon under way in China in 1989 was aborted by overwhelming military force. There is certainly value in avoiding over-radical dichotomies between old and new media, but it is also important to look at the similar and the dissimilar, the convergences and the clashes, between the two realms of media. In many developing countries (democratic or not), press freedom for the old media remains the primary issue simply because they are still the most extensive vehicles for journalism.

New media technologies are changing the panorama of traditional media and are being hastily adopted world-wide to join global communications and catch up with advance countries in scientific and economic development. Many of the traditional means of delivering information are being slowly superseded by the increasing pace of modern technological advance. Almost every conventional mode of media and information dissemination has a modern counterpart that offers significant potential advantages to journalists seeking to maintain and enhance their 'freedom of speech'. New media technologies have been described as tools to strengthen and weaken social democratisation, and to liberalise and control information flow. Excessive generalisations like techno-positivism, techno-neutralism and techno-negativism often fail to take into account various differences in the social environment where such technologies operate. As Sussman [5] noted, the nature of new information technologies entails pluralism, diversity and two-way interaction and thus reduces the potential for monolithic, centralised information control and direct or self-imposed censorship. If democratic communications are the basis of any democratic culture and political system, changes in such communications, brought about by new technologies, should also be expected to affect a country's culture and political systems. Today, many governments world over are worried more than ever about the political consequences of the new media penetrating their countries. They give a strong warning over the wide spread use of new electronic media, especially satellite TV broadcasting and insist that if we do not act resolutely and effectively now, the US and other Western countries may achieve their goals of disintegrating by transborder broadcasting and other new media technologies, just as they did to the USSR and other Eastern European countries'[6].

It is the further premise of the writer that these new media blitz will increasingly influence all countries, no matter how centralized their present form of governance. This suggests that there will be many more political revolutions across the planet attributable in large measure to the new communications technologies. Changes will occur within each nation large or small, rich or poor, of whatever present political and social orientation. These changes, moreover, will not be wrought in isolation. The new communications technologies will be most productive when they are joined together in a tissue of networks, 
both domestic and international. This will be the Integrated System of Digital Networks (ISDN).

ISDN, like the Agricultural and Industrial Revolutions before it, will not automatically enlist peoples or nations. Technology in itself cannot create new polities, but new communications technologies will become essential to economic and social development. Consequently, they will drive politics and speed up democratization. Political will is still needed to ensure such development and avoid the disadvantages of the new technologies; in brief, to avoid the recentralization of political systems through the misuse or exploitation of the networking aspects of ISDN. To skirt that negative possibility a new set of regulatory rules will be needed nationally and internationally. The great challenge in the thirty years ahead will be the creation of regulatory systems founded on democratic objectives - equitable for all citizens within countries; and for all countries, large or small, rich or poor. Regulators would replace censors in order to maintain pluralistic news and information systems within and between countries.

Freedom of the press was not created by the Founding Fathers for the convenience of either the politicians or the press; it was created as a guarantor and protector of an informed citizenry, without which we have no democracy. The history of communication has shown, the most fundamental conflict in communication often takes place between the outlook of the established authorities (responsible for maintaining the current order) and media demands for unrestricted freedom of expression [7]. The history of mass communication, in this sense, has evolved around conflicts between the government and the media. As revealed by many cases, advancement in media technologies, providing greater public space and new ways to break through information controls, often leads to new rounds of conflict. New media technologies here are referred to as technological progress in the fields of mass communication since the 1980s. As Wilson Wizard, Jr., put it, they include digital radio broadcasting, multi-media computers, wireless cable system, CD-ROM laser disks, direct broadcast satellites, advanced facsimile machines, intelligent telephones, consumer computer networks, portable electronic newspapers, and national videotext services (Wizard, 1994:2) The revolutionary role of SMS, Twitter and Facebook has succeeded in triggering and sustaining democratic political change in closed and repressive societies. The best part of these new media tools is that they are cheap, universal, pro-democracy, pro-freedom and pro-liberty. Today's technology also gives the media powerful new tools for intrusion into private lives. Cameras are smaller and easier to hide. Conversations are easily recorded surreptitiously. Computers and the Internet provide the ability to rummage through the closets of your life in ways that have never before been possible .orgies are known to affect various aspects of human life even though their invention may originally have had different aims. This is especially true of communication technologies, which often result in changes which are never part of the intention of their inventors [7].Indeed, not since the printing press was invented and the Word became free locally has such a swift transformation of the force of the Word taken place so globally. An era of citizen journalism and free media is upon us and this will have far-reaching consequences for democracy and accountability.

Among various arguments quoted about the development of new information technologies, there is a popular vision of the average citizen empowered by new media technologies, able to communicate honestly and directly, challenging established power and planning political actions that advance democracy [8]. If Gutenberg's Bible weakened the power of the church by passing the holy script to ordinary people for their own interpretation, connection to the Internet and the increasing penetration of overseas broadcasting may also open a Pandora's Box, where the government relies on information control to maintain its legitimacy and authority. All these contradictory manifestations of the new media are, however, inevitable consequences of the rise of new media technologies, the sudden winning of media freedoms and the proliferation of satellite and cable television. In times to come, they will surely be tempered by the demands of the economy and democracy and learn to become as responsible and accountable as the other pillars of the modern nation-state.

Press freedom is one of the corner-stones of democracy. The key to press freedom is the institutionalized commitment of government to permit the flow of ideas without prior or post influence or control by officials of the state. The hallmark of such an independent flow is diversity of news and information. This pluralism of ideas, including dissent from official policies, is fundamental. There is no single 'truth'. Through the ages, however, the nobility, religious leaders and secular officials have insisted otherwise. Today, in an increasingly complex world, proclaimers of a single truth in politics, economics, science or commerce are destined to be deputed by other authorities and, as the 1980s showed, by events. Right conclusions are more likely to be gathered out of the multitude of tongues than through any kind of authoritative selection.

In recent years, numerous international communication scholars have analysed the socio-economic, political and cultural implications for developing countries of the information revolution and the rapidly-emerging new communication technologies. On the one hand, some critics focus on the threat posed by the technolopes to the national sovereignty, independence and cultural autonomy of developing countries. On the other, more optimistic scholars see the new technologies as presenting ideal opportunities for Third World societies to leapfrog the development process into the information age?[9]Yet another group of scholars exult over the ability of new communication technologies to 'promote participatory democracy and decentralization, broaden the spectrum of choice, increase global interaction, expand the reach of information'?[10] The advent and diffusion of new communication technologies have facilitated the global flow of information. The new media technologies have brought about a quantum leap in the ability of people and nations to communicate with each other across time and distance[11]'.

New media have always posed a threat to the established order; that's why the fight against censorship is a constant battle. The nonstop pursuit of journalists has always been an expression of the deeply rooted faith that journalists have a message and a mission to create an atmosphere where the public can be made aware of what is going on around them. Media freedom, especially enhanced with the opportunities of new technologies, is increasingly understood as both an underpinning and a measure of democratization and development - and one that requires ongoing support. The press freedom theory is about to change the conventional ideas of its paradigm. It focuses on the current development of the Internet and other forms of computermediated communication - what Castells [12] calls the "Internet galaxy", drawing on Marshall McLuhan's description of the diffusion of the printing press in the West as' Guttenberg Galaxy' - the Internet has become implicated in various political and regulatory struggles, much of which has already begun [13]. Besides, the penetration of foreign/overseas broadcasting and satellite TV; challenges are posed by the new media technologies to government information control 
systems. The changing order of state, of power relation, emerging factor of political economy, democratic malpractice and ownership structures are demanding a fresh look into it. In assessing or measuring the state of press freedom of an individual country there is a need to look at the components dominating the decisions. The news media are in crisis across the developed world. Journalism as we know it is being described, obviously with some exaggeration, as 'collapsing', 'disintegrating', in 'meltdown'. In this digital age, there is gloom in most developed country, or 'mature', media markets over the future of newspapers and also broadcast television. The arrival of the digital revolution - the evolution of the Internet, the emergence of new forms of media, and the rise of online social networks - has reshaped the media landscape. There is a strong sense that 'the news industry is no longer in control of its own future' [14] and that it is technology companies like Google and the social media that lead the way and look set to hegemonise the public space that once belonged to the news media. As the communications landscape gets denser, more complex, and more participatory, the networked population is gaining greater access to information, more opportunities to engage in public speech, and an enhanced ability to undertake collective action.

Newsrooms are delightful studies of chaos. It's a high-pressure world where the timid are quickly discarded. Add online demands to the mix and the mind boggles. Once journalism was about who, where, what, when and why. Now it's the power of Twitter and new media. The worlds of media, content, branding, and messaging are changing so rapidly that it's not unrealistic to think a startup could appear tomorrow and rewrite all the rules again by the end of this decade. That kind of change requires adaptability, a willingness to collaborate, and near constant innovation. In much of the traditional media, newsrooms are being squeezed, local coverage diminished, and serious journalism abandoned. But this void is starting to be filled by independent reporters and innovative and collaborative" pro-am" and citizen journalism. They are using new media and new models to do in-depth investigative projects, find untold stories, and engage new audiences. Whether relying on contributions from readers, new tools and technologies, or old-fashioned, shoe-leather reporting, these projects are redefining journalism. For the past three years, discussions about the future of the news media have centered on the decline of the so-called golden age of journalism and the descent into a chaos characterised by splintered audiences, decimated balance sheets, and the muscling-in of amateurs. Fearing that their halcyon days as the guardians of information are numbered, many editors and journalists have engaged in collective navel-gazing, asking themselves: What went wrong? But is the future really so bleak? Is the decline a global phenomenon? Are we moving into a new 'golden age'? And what does it mean for press freedom? This is a time of crisis. With news organizations disappearing, the industry in disarray, a situation has arisen in which field of journalism is simply preoccupied with survival; many of the societal structures that customarily defend the press have been disrupted.

This brings us to a paradox, which seems to be central to this transformational age. In the midst of this old media crisis, more and more people are reading newspapers digitally and it is a global audience for the best publications. Worldwide, printed newspapers, with a reported circulation of 519 million, reach an estimated 2.3 billion people every day, 20 per cent more than the internet [15]. But the 'terms of trade' are shifting remorselessly in favour of the web, mobile, and newer interactive digital platforms. Many newspapers have excellent websites offering rich, many-sided, multi-media content, including long-form features, investigative articles, and thoughtful analysis. Several journalism schools round the world now take digital journalism seriously. It still comes mostly free-to-air but some major western newspapers have begun to price their digital content and some new revenue streams have opened up. Mobile platforms and tablets led by the iPad hold promise, with several newspapers and television channels coming up with innovative and attractive apps. But all this does not add up to a viable revenue and business model for digital journalism. The internet advertising model is doing exceedingly well but it is the search engines, above all Google, that take the lion's share of the revenue; the paid-content model is also well established on the mobile platform, what with hundreds of millions of users accepting 'monthly contracts, pre-paid phones, and paid-for apps', but here too, the new kids on the block, Apple and the mobile operators, take the bulk of the revenue [15].

The newspaper industry faces a double squeeze: the print business continues heavily to subsidize digital journalism, which cannot pay for itself by attracting enough advertising or subscriptions or a mixture of the two; and the new digital players put increasing pressure on newspaper circulation, readership, and the business itself. We must also be willing to invest not only in the technology, but also in professional and citizen journalism, developing media businesses, media law reform and authentic advocacy groups over the long-term -- even as we must continue to stand up for the immediate rights of citizens and journalists to express their views through new and old media alike. However, old courage and new tools still must draw on the collective strength of global public principle. Development of an open and vibrant media and truly protected freedom of speech may require years of effort.

Press freedom can be a very fragile flower indeed if journalists and the public are not vigilant. Press freedom often acts as a kind of bellwether of the direction an array of political and social freedoms are taking. Such freedoms are not privileges but rights. Anyone who interferes with these rights, whatever their motives may be, threatens the whole system with serious and permanent damage. If the press is restricted by government we will find ourselves on the slippery slope to authoritarianism. The media must be freed from the fetters of governments which see no role for it beyond entertainment and slavish obedience to its policies. In this age of globalisation of information and telecommunications technology, the news media is becoming increasingly privileged and powerful. If society demands that the media becomes more accountable, then it is a matter of answering the question -- who is watching the watchdog? To win the public trust in a democracy, the media can no longer cling to 'traditional catch cries' about a free press. The media must be prepared to reevaluate the substance of those catch cries and reexamine their own operations and the nature of the implicit contract they make with their audiences. Press freedom is like tending a garden, it's never done. It continually has to be nurtured and cultivated and the citizenry has to value it. It's one of those things that can slip away if we don't tend to it.

Changing mindsets is essential in times of transition. Journalists, who were used to deliver government-friendly information and were accustomed to self-censorship, are faced with the challenge of changing their editorial habits. Holding governments and powerful institutions accountable, and adopting the methods of investigative journalism are essential tasks in a new media context. Media must develop their role of watchdogs respecting ethical principles in accordance with international standards. For bigger actors, there is a tendency to take part in the rush to win the market, instead of fighting for enhanced 
quality according to international standards. New media outlets and established media groups find themselves in competition in a continually changing media landscape, which raises the question of their coexistence and cooperation. Editorial independence is often challenged by an unclear line separating the media owners from the editors or journalists especially when the same person occupies both functions. In such a context, it is vital to ensure transparency of ownership to avoid eroding freedom of expression, media plurality and diversity in content. The basic criteria's of quality journalism should be openly discussed and established among media practitioners. Sustainability of journalist training must be ensured and this would include follow-up assessments and refresher courses. To be effective, the training must connect with the local and national reality.

Not that long ago, journalism's transition from analog to digital looked a whole lot simpler, the road ahead appearing nearly as straight and narrow as orderly packets of bytes zipping down the line one after another. For a time, we even relied on a metaphor that, in retrospect, rings laughably naive. The Information Super Highway has been overtaken by a messier thicket of trails, many of which lead nowhere. And yet, with renewed signs of reportorial resolve stirring around the globe, journalists and non-journalists alike are uncovering paths that hold the promise of informing more people, more thoroughly, than ever before. As a result, new ways of communicating have enriched news and information resources and reshaped what was traditionally the realm of professional journalism expressed in newspapers and magazines, on radio and television. The challenge is to optimize the potential of digital media while not compromising political and civil liberties Likewise, governments and regulators need to respond to civil society's calls for open and affordable access to mass and community media. The world is immeasurably poorer without communication rights and press freedom. It is immeasurably enriched by the free flow of information and knowledge, which are the lifeblood of democracy.

The media is said to be the 'Fourth Estate'. This is so because they act as watchdogs that check and balance the powers of the other three branches of government - the executive, the legislature and the judiciary. In their plight to be the watchdogs, and to perform their noble duties and responsibilities, they are often caught in the web of uncertainties and trapped in the cauldron of ethical quandaries. They have to decide between news values and bad tastes; and between public's rights to know and national secrecy or invasion of privacy. Unlike doctors or lawyers who have statutory accountability, journalists have no extra rights and privileges from ordinary citizens. They do not even have the protection of 'shield laws' to avoid imprisonment when defying an order from a law court to divulge a professional confidence when they are bound by their code of ethics to protect their source. But the public, above anything else, have the right to be protected against misleading and distorted information. Hence, it is of utmost important that media practitioners should be ethical and responsible in news dissemination. Indeed, the universal standard demands that news dissemination be based on accuracy and impartiality. Media development seeks to support and promote a pluralistic, editorially independent and financially sustainable media sector. An independent media sector buttresses key governance goals such as voice, accountability, and transparency -- not through dissemination of messages about these issues, but through its very existence. The same principles apply to the new media as to the traditional media. The free flow of ideas byword and image is a prerequisite for any social and economic development. The efforts to support new communication technologies, therefore, must be placed alongside efforts to support press freedom. Efforts to support press freedom must be complemented with capacity-building efforts to strengthen professional standards and socio-economic programs to combat poverty. The impact of new media is, after all, dependent on quality of journalism and accessibility.

New media, which is a broad term that refers to the incorporation of traditional media with the interactive power of computer technologies and most importantly the internet, has not only redefined the way we communicate but has become part and parcel of our day-to-day lives.. The new media are not bridges between man and nature; they are nature. We enjoy unprecedented opportunities for expression thanks to new technologies and media. More and more people are able to share information and exchange views, within and across national borders. This is a blessing for creativity, for healthy societies, for including everyone in new forms of dialogue," Massive technological change over the past decade has created new opportunities for freedom of expression and information. Freedom of the press is, after all, an application of the individual human rights principle of freedom of expression. New media hold great potential as a resource for press freedom and freedom of expression. They serve as a platform for dialogue across borders and allow for innovative approaches to the distribution and acquisition of knowledge. These qualities are vital to press freedom. But they may be undercut by attempts to regulate and censor both access and content. Thanks, new media holds great potential as a resource for press freedom and freedom of expression. New media opens hitherto unseen opportunities as a platform for dialogue across borders, and allows for innovative approaches to the distribution and acquisition of knowledge. I would like to pick up on a thought when anybody cites government concerns about the media perceived as an 'all-powerful beast prowling" and a law unto itself. "For governments which fear newspapers there is one consolation. We have known many instances where governments have taken over newspapers, but we haven't known of a single incident in which a newspaper has taken over a government. The press is often a target of retaliation by those who feel threatened by freedom of expression and transparency in democratic processes. Journalists are often the first to uncover corruption, to report from the front lines of conflict zones, and to highlight missteps by governments. This work places many journalists in danger, and it is the duty of governments and citizens worldwide to speak out for their protection and for their vital role in open societies.

Massive technological changes over the past decade have created new opportunities for freedom of expression and information. Technological development has led the media to both expand and retract. Digital transmission has resulted in more and cheaper opportunities for broadcasters and greater choice for media consumers. Media organisations now disseminate information through a multitude of platforms in order to fulfill their audiences. The media has had to diversify how it delivers content, the speed of its delivery, and take account of information increasingly originating from non-media authors. Some media organisations have responded by owning large shares of the media landscape and such mergence in the sector can lead to concerns over diversity and plurality. With more opportunities comes more competition and media organisations quickly grow or fail. The new concept of 'citizen journalism' has developed to identify bloggers, social media users and other 'non-professional' information sources. Traditional media organisations no longer serve as gatekeepers and information has been democratised. With two billion people now online, the internet has become the public space of the $21^{\text {st }}$ Century. We have all witnessed the power that this surge in connectivity can have in shaping society and holding governments accountable. New 
media empowers individuals around the world to share information and express opinions in ways unimaginable just ten years ago.

The new media has taken over all the other four mediums of media, whether it is print, Radio, Television or cinema. All of them have become part of media. The new digital era has seen an increasing role of the Internet, blogs and social media as an arm to fight censorship and press freedom intimations. The internet permits an unprecedented empowerment of the individual. It is probably this feature, together with the speed and the global character of the internet that has made many governments worry about granting internet users the same right to freedom of expression as traditional media have in democratic societies. This quality of new media that is most disturbing to some governments is however likely to prove very resilient But at the same time, "many governments, fearful of this lack of control, are trying hard to restore or fortify barriers to trace, block, target and censor those who champion the truth. On the negative side, the internet has opened up extraordinary new possibilities for the widespread, damaging and sometimes dangerous manipulation of information which is difficult if not impossible to stem. This phenomenon will increasingly place a heavy responsibility on professional journalists to maintain high standards of fact-checking, honesty and objectivity. The very fundamentals of our societies and democracies will be lost if we are unable any longer to distinguish between true and false in terms of information."

Freedom of press remains as important as ever in the digital age, serving as a basis for democracy and human dignity everywhere. Around the world people are using new media in the call for freedom, transparency and greater self determination. We must always remember that it is not the tools, but the courageous people who use them - journalists and reporters and individual citizens - who are the human voice of freedom. In recent weeks we have seen the detention of prominent activists around the world who have made bold and creative use of new media to expose problems in their own societies.

While press freedom and freedom of expression are fundamental human rights, most countries have enacted national civil legislation limiting it in cases such as libel, breach of privacy and pedophilia. These matters may not be without controversy but, in general, such national legislation commands widespread support. Many of the oppressors' tactics show an increasing sophistication, from the statesupported email in China designed to take over journalists' personal computers, to the carefully timed cyber-attacks on news websites in Belarus". Censorship tactics include web blocking, used with particular effectiveness by Iran, denial of access, which is what Cuba does, letting a very small part of the population accessing to the Internet at home, while the vast majority required to use state-controlled access points with identity checks, heavy surveillance and restriction on access to non-Cuban sites. Many prominent professionals in the media world have warned that press freedom has deteriorated badly in Hungary, Romania, Bulgaria, Italy, France, Greece, Cyprus and Slovenia. Attacks against media freedom have taken different forms: through internal restructuring of public media and through new legislation, as well as simply by the countries' authorities spying on journalists. The United States fell more than 20 places, mainly because of ... judicial action that is undermining the privacy of journalistic sources... trying to force them to disclose their confidential sources. Canada also dropped several places due to decisions that weakened source confidentiality, turning some journalists into "court auxiliaries." France also slipped, mainly because of court-ordered searches of media offices, interrogations of journalists and the introduction of new press offenses.
Public broadcasters are singing the blues. Running ahead of private sector competitors blinded many to extravagance, or the appearance thereof. While few were truly fat with cash the guaranteed revenue streams hid a multitude of sins, real or perceived, and those became targets of publishers, politicians and other predators. The result is a new tune of slow, dark notes that leaves the audience hanging. On one hand, new media has given rise to largely speculative fears that link extremely rare but iconic events -- school shootings, abductions -- to our familiar daily interactions with the online world. On the other hand, the whole discussion of new media has given rise to some wishful thinking. So on one hand we have the fears, and on the other, the Dream. These worries and hopes are the basis for new questions that people spend more and more time debating. Can anything be more important than what happens inside our own homes or the promise of a new technology?

The real challenge is to fully exploit the potential of new media while not compromising civil liberties, including the right to privacy. Let us bear these considerations in mind as we reflect upon the challenges before us. Perhaps not coincidentally, in recent years there have even been attempts made to curtail press freedoms in Western countries. There will always be people who fervently wish the news media would just go away. By and large, those who fit this description fall into two groups: One composed of people who have wealth or power and fear losing it. The other consists of people who believe they have the ultimate truth and that nobody should be allowed -- publicly at least -to challenge their beliefs. We are at a unique moment in history when members of either group could, with relative ease; gain the upper hand in their efforts to strangle a free press. This is the great danger of our times.

There's good news and bad news about new media. First the good news: The Internet, mobile phones, and other types of "new media" are making information sharing infinitely easier. For the first time in history, there is a global platform for free speech and the possibility of a truly free press. But you knew this. The bad news is that freedom of the press is actually decreasing just about everywhere in the world! In a report released April 29, Freedom House - a watchdog group that monitors democratic issues around the globe - found that press freedom declined for the eighth consecutive year, and only one in six people live in countries with genuinely free media. And - as I learned for the first time the number of bloggers in prison almost surpasses the number of traditional print and broadcast journalists. The internet's influence has drastically changed the media landscape, often to the detriment of print newspapers. Is new media edging out accountability and standards with ill-informed opinion and user-generated rants? Or is it the evolution of journalism, breaking down barriers which previously restricted the flow of information and narrowed the range of debate?

Communication is a fundamental social process, a basic human need and the foundation of all social organization. It is central to the Information Society. Everyone everywhere should have the opportunity to participate and no one should be excluded from the benefits the Information Society offers."In drawing attention to these basic principles, I am under no illusion that the complex, real world problems that we face are thereby solved. It is an unfortunate truth that, in many countries, there is a very long road ahead of us in securing press freedom.

But these principles do provide a standard by which we may measure our actions and those of others. The fuller application 
and implementation of these principles through concrete action is something we should all be working towards.

We must first secure a full understanding on the challenges that new media face with respect to press freedom. As the impact of new media increases, so do regulation techniques that limit the free flow of information. New media are subjected to restrictions such as Internet censorship that would not be accepted in traditional media. Violations of freedom of expression are growing, and the need to discuss how to prevent undesired side effects of new regulation has become urgent. We must emphasize that free media, which are essential in upholding democratic societies, should not be hindered. Such an understanding must in turn be met with concrete efforts to affirm the place of new media alongside traditional media. It is essential that no new restrictions on the basic principles of press freedom and freedom of expression are applied with the introduction of new media. All citizens not only have the potential but also the right to express their ideas and opinions worldwide through electronic networks.

In addition, there are sometimes legislative measures, for instance, in the form of special laws to block sites that are considered to offer ways of obtaining information contrary to certain political, sexual, or moral standards. In addition, there are legislative acts that deal with security or confidentiality laws to protect personal data. While press freedom and freedom of expression are fundamental human rights, most countries have enacted national civil legislation limiting it in such cases such as libel, breach of privacy and pedophilia. These matters are not without controversy but, in general, such national legislation commands widespread support.

Another difficult challenge is the connection between the Internet and protection against terrorism. The balance between measures required for fighting terrorism and respect for fundamental rights is very difficult to find. There is a real risk that security measures may, directly or indirectly, undermine the very principles and rights that terrorism seeks to destroy.

Authoritarian governments and state institutions are becoming increasingly techno-savvy. They seek to control the public sphere and propagate their own political agenda to ensure broad legitimacy. Ending authoritarian rule is not only a matter of wiring enough people. Technology is a tool that can be made useful by political, economic and social actors. It is the experience of IMS from working around the world in difficult political environments that only by promoting very specific programmatic uses of new media and networked communications can impact be achieved.

The 'freedom of expression' as safeguarded by the Universal Declaration of Human Rights Article 19 has consistently been subject to intimidation by various social, political and economic actions in the sub-continent of South Asian democracies in the past few years. Lately in South Asian countries like Nepal, Sri Lanka, Pakistan and India the press has been attacked, journalists assassinated, threatened and intimidated in their endeavour to uphold the principles and ethos of freedom of press and freedom of expression. Though how dismal the situation maybe with press freedom and freedom of expression in South Asian countries, the new media technologies such as the Internet, hand-held devices (cell phones, PDAs) and wireless devices, and their applications like citizen journalism, blogs, YouTube and so on have provided promising opportunities to uphold freedom of press and freedom of expression in the sub-continent and elsewhere.
In characterising the stakes in all this, one can safely say that contestation around press freedom in general is fundamentally around public power - and in particular about that form of communication that deals with power, i.e. journalism. In all this, "press freedom" is of course a sub-site of wider power contestations. Its parameters are largely determined by broader balances of forces. Hence there are often correlations between different indices of freedom (see http:// en.wikipedia.org/wiki/List_of_indices_of_freedom). At the same time, what happens within the broad press freedom topography of struggle can have substantial repercussions in other realms. In whatever media realm, old or new, press freedom - as freedom for the institution of journalism - is thus a pivotal prize for power more broadly.

Against this background, what this paper tackles is the extent to which new media and traditional media are different creatures, and to what extent the rise of the new means an extension of an existing battle (an expanded "army" of players who favour press freedom), or a contest which also entails a qualititatively changed set of forces and fortresses. Further, it is important to probe to what extent, if there are differences related to the increasingly diverse vehicles and platforms for journalism, what these mean for the prospects of commonality of purpose as regards press freedom. Also addressed are the following questions:

* To what extent do the old(er) media use new platforms to amplify the space and extend the impact of their journalism in regard to press freedom? [16].

* Does new media, and specifically journalism in this realm, make a difference to both traditional media and to the wider political environment for generic press freedom?

* There is also the issue of the source, and play, of journalism in cyberspace. Thus, besides the presence of traditional media, what about bloggers who do journalism (notwithstanding that only a minority do so)? How about search engines' news offerings and even non-media institutions publishing "journalism" in various forms? Who, in short, are the direct stakeholders of press freedom in the new media terrain?

* Finally, how do all these play out on a global scale, and with particular regard to press freedom in the "developing countries"?

The face of Indian media has been fast changing with the growth of the Internet, the phenomenal rise of satellite and cable networks, the continuing growth of regional press, despite various challenges and the blurring of lines between news and entertainment. But there is a sort of 'crises in the present media due to processes of commercialization, mercerization and commoditization. This has led some to present a pessimistic view of the media, to emphasize the ascendancy of 'infotainment' over 'serious' reportage and analysis of politics. It is also often remarked that the quality of 'serious' political journalism is steadily declining, with a dilution in its substantive political content to the detriment of the democratic process. An opposite view asserts not that there is too little serious politics in the media, but too much. This is seen as a kind of information overload that bores audiences and diminishes public interest. Still others have argued that media is an elitist bourgeois construct, reflecting essentially bourgeois interests and values and conditions of existence and can thus never serve the genuine interests of the people as a whole. Despite its democratic façade, it is said that the media remains exclusive, and people as a whole feel no real involvement in a process which appears to give them power but in reality does not. 


\section{Protection of Intellectual Property}

As the new communication technologies proliferate, the need to protect individual creativity and especially intellectual products will increase exponentially. From 1982 to1986 seventeen nations passed new copyright laws concerned mainly with computer software, semiconductor products, home taping, piracy, satellite broadcasting and folklore. National and international discussions of copyright include the distribution of radio and television programmes by cable, public lending and rental of copyrighted material, and works in the public domain." 'Piracy of intellectual property is costing the United States tens of billions of dollars in lost sales and royalties,' said Gary M. Hoffman, principal author of a 1989 study at Northwestern University. It will be particularly difficult to register and monitor news and informational messages created electronically and transmitted great distances by computers over telephone lines. For years, global news flows and video cassettes have been pirated without credit or compensation to the producers. Photocopies make it easy to pirate books, magazines and articles. Telefax enables intellectual pirates to operate at some distance from source. Off-the-air videotaping simplifies the theft of news, information and entertainment programmes for illegal use and sale. A new hazard is appearing in the form of photojournalism. The new digital photographic systems can alter pictures undetectably. National Geographic magazine in 1982 slightly shifted one of the Great Pyramids at Gaza to enable a photo to fit on the magazine's cover. Digital photography is faster and cheaper but tampering must be banned if the product is to be credible. These and other breaches of intellectual proprietary rights will become far more widespread in the age of ISDN The networking of vast numbers of national and international networks - conveying all manner of news, commentary and background information - will raise the problem to the level of major international concern.

International copyright conventions should be thoroughly reexamined. Authors and publishers - print, broadcast and electronic must be protected against plagiarism and financial theft. At the same time, others near and far should be able to examine these works for their o w $\mathrm{n}$ information, and to advance their intellectual efforts. The balancing of these two rights will be difficult. As the age of ISDN provides unparalleled opportunities for mass education and mass communication, the copyright system must balance the rights of creators and users.

It is already clear that technological development in the field of communications is moving faster than regulators can act. It is far easier to cite the present and potential conflicts of rights and interests than to provide equitable recommendations in advance. Several guidelines, however, can be set down:

1. The new communication technologies should be treated by all governments as vital instruments of free expression, and the free flow of their content protected from governmental control.

2. As soon as possible, all the new technologies should be standardized so that everyone everywhere can have equal access to the networks and the archival content.

3. Regulatory supervision may be needed to enhance the diversity of content by preventing the monopolization of communication systems by governments or entrepreneurs, and encouraging competition among \&verse systems.

4. International communication systems should not be regulated as commercial trade-offs (e.g. under the General Agreement on Tariffs and Trade - GAIT), but rather as channels of free expression, a basic human right.

5. Developed nations should acknowledge the long-term value to all countries of assisting poorer nations to build communication infrastructures that will enable them to join the global networks. The conflict between nations regarded as suppliers and others intent on building their own infrastructure should be quelled in international regulatory and development-aid forums. Third World countries should be encouraged, for example, to use digital systems and fiber optics in order to leapfrog the older, more expensive communication systems.

6. Protective rules should be enforced globally to defend intellectual creators against pirating of their products.

7. Transborder data flows - essential to all peoples everywhere -should not be regarded either as an unlimited instrument for the defence of national sovereignty or commercial property, or as an unlimited channel for the transfer of data of a personal nature from one country to another.

8. Earnest efforts should be made by developed countries to help Third World nations enhance their human and technological capacities for the Age of ISD

\section{When Old Media Become New: Significance for Press Freedom}

Moving now from general considerations discussed above towards the more empirical level, it is possible to assess some of the more concrete specifics of press freedom and new media forms. The comparative (if exaggerated) ease of entry into online electronic publishing, as distinct from print or broadcast, in countries with a minimum of Internet connectivity means that new media objectively widens the environment where press freedom comes into play. This is especially important in countries with low media density, where arguably the more information on offer, the better. Better still, such international publishing at least serves the vast diasporas of many of these countries, as well as creates an international presence for the knowledge within the wider global information resource base.

But old media have only embraced the online environment belatedly, and developments are still minimal in many developing countries in particular. In the developed countries, some of this expansion into cyberspace was defensive - seeking opportunities in markets where new competitors foraged (including scavenging off old media's offerings), and following migrating audiences or intercepting a new generation [17]. In many developing countries, in contrast, it was idealistic in the sense of wanting to "get the message out" on all available platforms. It was also to serve the diaspora and the outside world, and indeed also a matter of professional pride. Nowhere, despite some initial illusions, was it originally a matter of making serious profits - at least in the early days. It was, instead, an exercise in experimentation that actualised the freedom (of the press) to publish. Whatever the motivation, it should be welcomed, and encouraged. But at the same time, it amounts in a sense only to a quantative extension of journalism. Indeed, although many models exist [18], most online newspapers remain heavily dependent on content from their print parents. Yet, as is well-known, new media platforms also make possible a qualitative change.

As is well known, the Internet in particular allows for a journalism 
empowered by interactivity, hyperlinking, peer-to-peer file exchange, enhanced content, increased depth and multi-media forms of storytelling. The Utopian vision of seeing this happen is not restricted to developed countries [19]. But even in the developed world, such possibilities are seldom or only partially realised. "What emerges from observation of online news in action, and from discussions with those providing its content, is far from a revolution in media, but an expression of the cautious continuity, if not inertia, of media content and practice" [16]. Some evidence from developed countries is also that citizen forums, offering the potential for greater journalist and audience interaction, have failed due to lack of interest among both parties $[17,20]$. Indeed, "while new media use can be viewed as a form of 'productive consumption', not all users deploy their productivity in the same way and many are happy to defer productive control to producers" [21].

One reason for this phenomenon is that old styles and habits of both producers and consumers are simply transplanted from traditional media into the new media universe[21]. Another reason is that resources - and investment - in training and talent to exploit new media's strengths is not easily forthcoming, and especially in developing countries when infrastructure is still limited bandwidth costs exhorbitant and viable business models still unproven. Thus, many websites of media in poorer countries consist only of a portion of repurposed content from the parent platform; they also lack archives and proper search capabilities, let alone instances of multi-media or interactive journalism. This is one reason perhaps why these platforms are not treated by many governments as significant. State action against online newspapers (as in Zambia and Zimbabwe) has been a function of repressing the parent platform, rather than special problems unique to the new media as such.

If old media have impacted on new media via a fairly conservative presence there, in both developed and developing countries the question arises as to whether there has been any reverse influence. The general argument is that there has been some, and that this has some bearing on press freedom. Thus, there are many cases where the participatory ethos of new media has encouraged old media to open up to audiences - (although, understandably, stopping short of transmutating from mainstream into community media). The main model in the developing world has been to encourage the use of cellphones for voice and text contributions. This audience involvement, accelerated by Internet's example, can only be good for fostering a culture that values press freedom more broadly.

In recent years, new media has also influenced old media (mainly in developed countries) in the form of traditional journalists producing blogs - either privately, or as an add-on to their jobs. In this way, blogging is recognised and even adopted by the traditional as a complementary form of "participatory media" which can enhance connections between old media journalists and the communities they serve [22,23]. It has been noted, though, that this particular strand of blogging often tends to keep to a "traditional journalistic gatekeeping role by incorporating limited or no material from users, despite the inherently conversational and participatory nature of the format" [24]. Some practitioners have also run into problems with their media companies for their blogs [25]. However, while there are understandable parameters that may carry over into blogs by journalists working for the media industry, the point is that blogs per se should be different in some ways (eg. more opinionated, more interactive).

\section{Conclusion}

This paper has, in effect, argued that new media should not be seen in isolation of old media, and that neither should press freedom be seen in dualistic terms. There are strong linkages between all. Implicit in all this is that press freedom in both old and new realms is internationally significant, and indeed an interdependent terrain of contestation on a global scale. A violation of press freedom in regard to old media in one country deprives persons in that country of information, and all other countries indirectly. When there is a lack of press freedom on the Internet, with its international reach, then the globe is directly deprived of significant knowledge. When China censors the Internet, other regimes see they can follow suit. Conversely, when a blogger reports journalistically from a repressive country, so elsewhere do others with a vested interest in press freedom take inspiration. The flame of press freedom in new media in developed countries, can also take heart from brave struggles for press freedom in the old media in many developing countries.

Looking ahead, given the higher penetration of cell phones than computers in the developing countries, the potential of these devices to become the primary platforms for new media (and thence a degree of journalistic content) is something to watch. The functionality of these handhelds continues to multiply, and it is likely that they will increasingly double up as one-to-many media receivers, peer-to-peer dissemination devices, and journalistic content creation tools [26]. Next generation phones will also enable wireless Internet access, introducing a mobile dimension to Internet media (and thence to press freedom). It will take time to develop journalistic content that is tailored to exploiting this particular platform and there are issues related to the small screen size of most portable devices. For example, there is sometimes skepticism about the prospects for television on cell phones, given the small size of the screen.

However, picture this, literally: cell phones with built-in dataprojectors able to cast large-size images of content received onto walls or other surfaces. Whether journalistic content for such communications then comes from mobloggers or TV companies or other players is not important. Either way, the effect would certainly be to extend press freedom in developing countries in particular, especially in those where traditional broadcast content is tightly controlled.

In conclusion, a holistic approach, nonetheless sensitive to distinctions, is what is called for in assessing new media and press freedom in the developing world. The pace of technology means that the world now seems unlikely to ever reach a historical stage where there is just talk of "media" and no such entity exists as "new media". Even clothing, for example, may one day become a major medium for journalism. Nonetheless, what remains constant is that whether old, new or futuristic, the historical achievement of press freedom is of enduring importance for all platforms and for all countries. The rights to freedom of expression, information and association are not abstract principles; they are rights that states have an obligation to fulfill.

\section{References}

1. Bruns A (2008) Life Beyond the Public Sphere: Towards a Networked Model of Political Deliberation. Information Polity 13: 65-79.

2. Oyeleye A (2004) The Mediation of Politicians and the Political Process inNigeria. Parliamentary Affairs 57: 157-168.

3. Kuper A, Kuper J (2001) Serving a New Democracy: Must the Media "Speak Softly? Learning from South Africa. International Journal of Public Opinion Research 13: 355-376. 
4. A description of new communication technologies may be found in, for example, R. Brown, 'New Technologies in Communication: A General Description', Media Development, 30, 4, pp. 3-7; B. Maddox, 'The Born-Again Technology', The Economist, 22 August 1981, pp. 3-46 7, 10-21; F. Williams, The Communications Revolution, Beverly Hills, Calif., Sage, 1982

5. Sussman L (1989) Power, the Press and the Technology of Freedom. New York: Freedom House.

6. Yang W (1994) Speech on satellite broadcasting. Beijing Spring 93-94.

7. McQuail D (1992) Media Performance: Mass Communication and the Public Interest. London: Sage Publications.

8. Wasko J, Mosco V (1992) Democratic Communications in the Information Age. Toronto: Garamond Press.

9. The range of critical studies on the implications of $n$ e $w$ communication technologies for the developing world includes, for example, Jorg Becker et al. (eh.), C o m m unication and Domination: Essays to Honour Herbert I. Schiller, Norwood, N.J., Ablex, 1986; C. J. Hamelink, Cultural Autonomy in Global Communication, New York, Longman, 1983; K. Nordenstreng and H. I. Schiller (eds.),National Sovereignty and International Communication: A Reader, Norwood, N. J., Ablex, 1979; A. Smith, G e o-politics of Information: $\mathrm{H}$ ○ w Western Culture Dominates the World, London, Faber and Faber, 1980; M. Traber (ed.), The Myth of the Information Revolution: Social and ethical Implications of Communication Technology, London, Sage, 1986; L. U. Uche, 'Mass Communication65 and Cultural Identity: The Unresolved Issues of National Sovereignty and Cultural Autonomy in the Wake of New Communication Technologies',AfricaMediaReview. 3,1, 1988 pp83-105.

10. Mehra A (1988) Harnessing New Communication Technologies for development inAsia. Media Asia 15: 63-67.

11. Giffard AC (1987) The Myth of New Communication Technologies as a Quick Fix for Information Imbalances. KEIO Communication Review 8: 75-89.

12. Castells M (2001) The Internet Galaxy: Reflections on the Internet, Business and Society, Oxford: Oxford University Press.

13. Shapiro A L (1999) Think Again: The Internet. Foreign Policy 115: 14-27.

14. Rosenstiel Tom, Mitchell Amy (2011) The State of the News Media 2011
Overview, Pew Research Center's Project for Excellence in Journalism: ttp:// stateofthemedia.org/2011/overview-2. World Newspaper Congress: http:// www.wan-ifra.org/articles/2010/11/26/world-press-trends-and-more-reports.

15. Riess, Christoph (2011) World Press Trends 2011, WAN-IFRA press release, October 13, 2011: http://www.thehindu.com/news/resources/article2548460. ece); and slide presentation by CEO, WAN-IFRA at the $63^{\text {rd }}$.

16. O'Sullivan J (2005) Delivering Ireland Journalism's Search for a Role Online. Gazette 67: 45-68.

17. Benson R (2005) Book Review. Pablo Boczkowski, Digitizing the News: Innovation in Online Newspapers. Cambridge, MA: MIT Press, 2004. New Media and Society $7:$ 854-862.

18. He Z, Zhu JH (2002) The Ecology of Online Newspapers: the Case of China Media, Culture \& Society 24: 121-137.

19. Hattatuwa, S. 2006. Public service broadcasting. Using technology for democracy. http://www.comminit.com/redirect.cgi?r=http://ict4peace.wordpress com/2006/05/19/publicservice-broadcasting-using-technology-for-democracy/ Accessed on 5 January 2007

20. Boczkowski P (2004) Digitizing the News: Innovation in Online Newspapers MIT Press, Cambridge MA

21. Kerr A, Kücklich J, Brereton P (2006) New media - new pleasures? International Journal of Cultural Studies 9: 63-82.

22. Blood R (2003) Weblogs and Journalism: Do They Connect? Nieman Reports 57: $61-3$.

23. Mitchell B (2003) Weblogs: A Road Back to Basics. Nieman Reports 57: 65-68.

24. Singer J B (2005) The political j-blogger 'Normalizing' a new media form to fit old norms and practices. Journalism 6: 173-198.

25. Hull D (2006/7. Blogging between the lines. American Journalism Review. December 2006/January 2007. www.ajr.org/Article. asp?id=4230. Accessed 5 January 2007.

26. May H, Hearn G (2005) The mobile phone as media. International Journal of Cultural Studies 8: 195-211. 